\title{
Visible-Light-Induced Bactericidal Efficacy of a Platinium-Doped Titanium Photocatalyst
}

\author{
Fereshteh Mohammadi ${ }^{1}$, Mohammadreza Nejadmoghaddam ${ }^{1}$ and Amir-Hassan Zarnani ${ }^{2,3^{*}}$ \\ ${ }^{1}$ Nanobiotechnology Research Center, Avicenna Research Institute, ACECR, Tehran, Iran \\ ${ }^{2}$ Department of Immunology, School of Public Health, Tehran University of Medical Sciences, Tehran, Iran \\ ${ }^{3}$ Avicenna Research Institute, ACECR, Tehran, Iran
}

*Corresponding author: Amir-Hassan Zarnani, Department of Immunology, School of Public Health, Tehran University of Medical Sciences and Avicenna Research Institute, ACECR, Tehran, Iran, Tel: +98 21 22432020; E-mail: zarnania@gmail.com; zarnania@sina.tums.ac.ir

Received date: November 14, 2018; Accepted date: December 06, 2018; Published date: December 13, 2018

Copyright: (C) 2018 Mohammadi F, et al. This is an open-access article distributed under the terms of the Creative Commons Attribution License; which permits unrestricted use; distribution; and reproduction in any medium; provided the original author and source are credited.

\begin{abstract}
$\mathrm{TiO}_{2}$ photocatalyst has been known to exhibit a notable disinfecting activity against a broad spectrum of microorganisms. Ultraviolet (UV) irradiation is damaging for human chronic contact to UV at the level to excite $\mathrm{TiO}_{2}$, which is photocarcinogenic. For this study photocatalyst possessing bactericidal activities that could reduce the bacterial population of all tested pathogens when illuminated by visible light was selected. We shifted irradiation wavelength of $\mathrm{TiO}_{2}$ nanoparticles (NPs) from far UV spectrum to visible (Vis) wavelengths by Platinum (Pt) doping. $\mathrm{TiO}_{2}$ and Pt-doped $\mathrm{TiO}_{2}\left(\mathrm{Pt} / \mathrm{TiO}_{2}\right)$ NPs were synthesized via the sol-gel method in the form of powder and suspension, respectively. XRD, DRS, TEM and SEM techniques and EDX analysis were used to characterize the structure and properties of photocatalysts. Functional activity of both NPs was assessed in vitro by testing bactericidal activity against Escherichia coli and methicillin-resistant Staphylococcus aureus under UV and Visible irradiation. The results showed that the sizes of $\mathrm{TiO}_{2}$ and $\mathrm{Pt} / \mathrm{TiO}_{2}$ nanoparticles were in the range of 20 to $50 \mathrm{~nm}$ with high crystallinity in the anatase phase. The minimum inhibitory concentration (MIC) of $\mathrm{TiO}_{2}$ and $\mathrm{Pt} / \mathrm{TiO}_{2} \mathrm{NPs}$ was found to be $0.125 \mathrm{mg} \mathrm{mL}^{-1}$. Interestingly, Pt-doping resulted in a marked shift in irradiation wavelength toward Vis spectrum with as almost the same growth inhibition efficacy as $\mathrm{TiO}_{2}$ at UV irradiation. $\mathrm{TiO}_{2} \mathrm{NPs}$ reduced the growth rate of $E$. coli and $S$. aureus under UV irradiation for $24 \mathrm{hr}$ by $94.3 \% \pm 0.12$ and $98 \% \pm 0.16$, respectively; while $\mathrm{Pt} / \mathrm{TiO}_{2} \mathrm{NPs}$ inhibited growth rate of aforesaid bacterial species at the same time period under Visible irradiation. After $24 \mathrm{hr}$, growth inhibitory action of $\mathrm{Pt} / \mathrm{TiO}_{2} \mathrm{NPs}$ on $E$. coli and $\mathrm{S}$. aureus reached to $86 \% \pm 0.11$ and $90 \% \pm 0.14$, respectively. Taking together, we observed that visible-light responsive platinum-containing titania $\left(\mathrm{Pt} / \mathrm{TiO}_{2}\right)$ exerted high antibacterial property against pathogenic bacterial strains taken into consideration that apparent quantum efficiency for visible light-illuminated $\mathrm{Pt} / \mathrm{TiO}_{2}$ is relatively higher than titania-based photocatalysts.
\end{abstract}

Keywords: Bactericide; Nanoparticles; Photocatalyst; Sol-gel; Titanium dioxide

\section{Introduction}

A wide variety of active chemical agents exhibit bactericidal activities. Some of the most widely used, including alcohols, iodine, and chlorine, have been employed for a long time in disinfection and preservation [1].

Nowadays, nano metal, metal oxide and their compounds are used widely in antimicrobial application research [2-5], such as $\mathrm{Ag}[6,7]$, $\mathrm{CdO}$ [8], $\mathrm{Fe}_{2} \mathrm{O}_{3}$ [9], $\mathrm{TiO}_{2}$ [10-15], $\mathrm{CuO}$ [16], $\mathrm{MgO}$ [17], $\mathrm{Mg}(\mathrm{OH})_{2}$ [18], and $\mathrm{ZnO}[19,20]$. Among nanometal oxides, Photocatalytic titanium dioxide $\left(\mathrm{TiO}_{2}\right)$ substrates have been shown to eliminate organic compounds and to function as disinfectants. $\mathrm{TiO}_{2}$ nanoparticles have been considered in a wide range of applications because of their varied functional potential including photocatalyst, dye-sensitized solar cells, gas sensor and especially in biological and pharmaceutical applications in nanomedicine. These NPs have attracted great interest in their development as potential antibacterial drugs [21,22].

Upon the irradiation of a $\mathrm{TiO}_{2}$ surface with photons of wavelength $\leq$ $385 \mathrm{~nm}$, an electron is excited from the valence band to the conduction band, thus forming an electron-hole pair. The photogenerated holes and electrons react with water molecules attached to $\mathrm{TiO}_{2}$ surfaces in the presence of oxygen to form hydroxyl radicals and other reactive oxygen species (ROS) such as superoxide ions [23]. It subject of investigation whether these ROS are directly counter parting in bacterial inactivation. Moreover, it remains unclear what conditions of irradiated light necessitate the activation of ROS generation.

Reactive oxygen species (ROS), such as $\mathrm{OH}^{*}, \mathrm{O}_{2}^{-}$and hydrogen peroxide $\left(\mathrm{H}_{2} \mathrm{O}_{2}\right)$ generated on irradiated $\mathrm{TiO}_{2}$ surfaces, have been shown to operate in concert to attack polyunsaturated phospholipids in bacteria [10]. In addition, it has been shown that photo-irradiated $\mathrm{TiO}_{2}$ catalyzed site-specific DNA damage via the generation of $\mathrm{H}_{2} \mathrm{O}_{2}$ [24]. These findings suggested that $\mathrm{TiO}_{2}$ might exert antimicrobial effects similar to those of the peroxygen disinfectant $\mathrm{H}_{2} \mathrm{O}_{2}$ [1]. The oxidation of bacterial cell components, such as lipids and DNA, might, therefore, result in subsequent cell death [10].

It has been reported that biophysical interactions occur between NPs and bacteria such as biosorption, NPs breakdown or aggregation, and cellular uptake with effects including membrane damage and toxicity $[11,25]$. The mechanisms of NPs inhibitory effect on the bacterial growth has been less well understood so far. It has been reported that the size and surface modifications of NPs could affect their antibacterial function $[11,23,26]$. 
Several physical and chemical techniques such as sonochemical, hydrothermal, solvothermal, reverse micelles, chemical vapor deposition or light-induced chemical vapor deposition [27], and solgel reaction have been used to obtain $\mathrm{TiO}_{2} \mathrm{NPs}$. Among them, the relatively simple sol-gel method is the most widely used technique due to the advantage of shorter processing time at lower temperatures $[28,29]$.

To enhance the photocatalytic effect in the visible light region, many producing methods were proposed to dope trace impurity in $\mathrm{TiO}_{2}$ including ion-assisted sputtering, plasma irradiation, ion-implantation, Chemical Vapor Deposition (CVD) and sol-gel. The visible light photoactivity of metal-doped $\mathrm{TiO}_{2}$ arises from a new energy level produced in the band gap of $\mathrm{TiO}_{2}$ by the dispersion of metal nanoparticles in the $\mathrm{TiO}_{2}$ matrix. An electron can be excited from the defect state to the $\mathrm{TiO}_{2}$ conduction band by a photon with energy equals ho $<3.2 \mathrm{eV}[30-33]$.

The main purpose of this study was the evaluation of $\mathrm{TiO}_{2}$ and $\mathrm{Pt} / \mathrm{TiO}_{2} \mathrm{NPs}$ efficiency for the inactivation of Escherichia coli and Staphylococcus aureus bacteria strains. We demonstrated that Platinum-doped $\mathrm{TiO}_{2}$ substrates have superior visible-light-induced bactericidal activity against two types of bacteria strains compared to the pure $\mathrm{TiO}_{2}$ substrate. Our data suggest that $\mathrm{Pt} / \mathrm{TiO}_{2}$ is an effective antibacterial photocatalyst which is user-friendly compared to traditional UV-driven $\mathrm{TiO}_{2}$ photocatalysts.

\section{Materials and Methods}

\section{Bacterial strains}

Standard strains of Escherichia coli (ATCC O55B5) and Staphylococcus aureus (ATCC MRSA 25923), as representative gramnegative and gram-positive bacteria respectively, were used in this study.

\section{Chemicals}

For the preparation of preliminary $\mathrm{TiO}_{2}$ suspension, the following materials were used: Titanium tetrachloride $\left(\mathrm{TiCl}_{4}, \mathrm{M}=189.79\right)$; Nitric Acid $\left(\mathrm{HNO}_{3}, \mathrm{M}=63\right)$; Ammonia $\left(\mathrm{NH}_{3}, \mathrm{M}=17\right)$, and Silver nitrate $\left(\mathrm{AgNO}_{3}, \mathrm{M}=169.87\right)$. Also, a chloroplatinic acid solution $\left(\mathrm{H}_{2} \mathrm{PtCl}_{6}, 8\right.$ wt\% in $\left.\mathrm{H}_{2} \mathrm{O}, \mathrm{M}=409.81\right)$ and Ethanol $\left(\mathrm{C}_{2} \mathrm{H}_{5} \mathrm{OH}, \mathrm{M}=46\right)$ were used for the preparation of Pt-doped $\mathrm{TiO}_{2} \mathrm{NPs}$. All of the materials were obtained from Sigma Chemical Co, USA.

\section{Preparation of anatase $\mathrm{TiO}_{2}$}

In a typical preparation process of $\mathrm{TiO}_{2}$ nanoparticles, ammonia solution $(2.5 \% \mathrm{v} / \mathrm{v})$ was added dropwise to $20 \mathrm{~mL}$ of Titanium tetrachloride $\left(\mathrm{TiCl}_{4}, \mathrm{Merck} \geq 98 \%\right.$ ) as starting material at room temperature on the magnetic stirrer for an hour to form a suspension with neutral $\mathrm{pH}$. Deionized water was then introduced to the suspension to total volume was reached $500 \mathrm{~mL}$. All additions were accompanied by vigorous stirring for an hour. $\mathrm{Ti}(\mathrm{OH})_{4}$ suspension was prepared, then washed with deionized water several times to remove the chloride ions. Subsequently, in order to produce a stable sol, this suspension was stirred at room temperature for about $24 \mathrm{~h}$ and then nitric acid was added dropwise to the mixture until the $\mathrm{pH}$ lay between 2 and 3. Therefore, a stable $\mathrm{TiO}_{2}$ sol was formed. In order to obtain $\mathrm{TiO}_{2}$ photocatalyst powder, the sol was dried and calcined for $3 \mathrm{~h}$ at $500^{\circ} \mathrm{C}$.

\section{Synthesis of $\mathrm{Pt} / \mathrm{TiO}_{2}$ by photoreduction}

$100 \mathrm{mg}$ of synthesized $\mathrm{TiO}_{2} \mathrm{NPs}$ was added to $10 \mathrm{~mL} \mathrm{H}_{2} \mathrm{PtCl}_{6}$ of an aqueous metal salt solution $(2.5 \mathrm{mmol} / \mathrm{L})$, and then this mixture was dispersed in $200 \mathrm{~mL}$ of deionized water in a Pyrex flask under stirring. This flask was exposed to a mercury lamp (125W) for $1.5 \mathrm{~h}$. Then the powder was collected by centrifugation and washed twice by deionized water and ethanol. Finally, the resulting powder was dried at $60^{\circ} \mathrm{C}$. The final product had the Pt contents of $0.1 \%$.

\section{Microbiological experimentation}

Bacterial strain and growth media: Antimicrobial activity of $\mathrm{TiO}_{2}$ and $\mathrm{Pt} / \mathrm{TiO}_{2} \mathrm{NPs}_{\text {were evaluated using Escherichia coli (ATCC O55B5) }}$ and Staphylococcus aureus (ATCC MRSA 25923), as representative Gram-negative and Gram-positive bacteria strains, respectively. The bacteria strains were grown overnight in a Nutrient-Broth (NB) medium and incubated under aerobic conditions at $37^{\circ} \mathrm{C}$ with shaking at $250 \mathrm{rpm}$.

Evaluation of bactericidal effect of $\mathrm{TiO}_{2}$ and $\mathrm{Pt} / \mathrm{TiO}_{2} \mathrm{NPs}$ : Ten $\mu \mathrm{L}$ of each bacteria stock were added to $3 \mathrm{~mL} \mathrm{NB}$ and cultivated aerobically at $37^{\circ} \mathrm{C}$ for $24 \mathrm{~h}$ were then collected by centrifugation at $3000 \mathrm{rpm}$ for $10 \mathrm{~min}$ at $4^{\circ} \mathrm{C}$, washed three times with $3 \mathrm{ml}$ sterile phosphate-buffered saline (PBS) and resuspended in PBS. Optical density (OD in 600nm) of bacterial suspension was adjusted to 0.1 , the cell density corresponding to 106-107 colony forming per milliliter (CFU/ml). Two hundred $\mu \mathrm{l}$ of the suspension was spread onto Luria-Bertani (LB) agar plates whose surfaces had been smeared with $50 \mu \mathrm{g} / \mathrm{ml}, 125 \mu \mathrm{g} / \mathrm{ml}$ or $250 \mu \mathrm{g} / \mathrm{ml} \mathrm{TiO}_{2}$. Culture plates without NP coating served as controls. $\mathrm{TiO}_{2}$-smeared bacterial culture plates were irradiated with a UV germicidal lamp $(15 \mathrm{~W})$ at a constant distance of $54 \mathrm{~cm}$ from the plate surface for 10, 20 or 30 seconds. Immediately after UV irradiation, the plates were incubated at $37^{\circ} \mathrm{C}$ overnight. Optimal concentration and exposure time was then selected based on the maximum growth inhibition rate and applied for exposure of $\mathrm{Pt} / \mathrm{TiO}_{2}$-smeared plates to a visible mercury lamp $(125 \mathrm{~W})$ at the same distance mentioned above. All experiments were repeated three times.

Enhancement effect evaluation: Also the antibacterial efficacy of the $\mathrm{TiO}_{2}$ and $\mathrm{Pt} / \mathrm{TiO}_{2} \mathrm{NPs}$ was determined using two shake flask methods; one with $\mathrm{NB}$ as the medium, and another with $\mathrm{NB}$ and nanoparticles. In the case of the NB test, bacterial growth was monitored by measuring the optical density of the medium over time. The microbial reduction percentage with the $\mathrm{TiO}_{2}$ and $\mathrm{Pt} / \mathrm{TiO}_{2}$ NPs for both species of bacteria is shown in Tables 4 and 5 respectively.

\section{Result}

\section{Chemical analysis}

Characterization of the prepared Titanium dioxide and platinum doped to Titanium dioxide nanoparticles was performed with different physicochemical methods. The crystalline structure of $\mathrm{TiO}_{2}$ nanoparticles was assessed and characterized by X-Ray Diffractometer (XRD D4-BRUKER and $\mathrm{Cu}-\mathrm{Ka}$ radiation at $30 \mathrm{kv}$ and $20 \mathrm{~mA}$ ). Also, the Diffuse Reflectance Spectra (DRS Shimadzu-2550) of resulting samples were recorded by UV-Vis spectrophotometer. Morphological studies were carried out using a Scanning Electron Microscope (SEM Philips-XLФ30 model) and Energy Dispersive X-rays (EDX) analysis. Also, the particle size of the nanoparticles was calculated using 
Transmission Electron Microscopy (TEM) was performed with a Jeol JEM- $2100 \mathrm{UHR}$, operated at $200 \mathrm{kV}$ that were previously air-dried.

\section{Antimicrobial activity evaluations}

The apparatus for testing the antimicrobial activity was composed of a woody box with a germicidal lamp as UV light source and tungsten lamp as visible light source, a Petri dish as the cover material.

\section{X-ray diffraction}

To study the crystallization process and phase identification, X-ray diffraction (XRD) of nano $\mathrm{TiO}_{2}$ powder was analyzed. As shown in Figure 1 in the X-ray diffraction pattrn of $\mathrm{TiO}_{2}$ poeder, peaks were observed at $2 \theta$ of $25.18^{\circ}, 37.88^{\circ}$, and $48.14^{\circ}$ which can be indexed as (1 $\left.\begin{array}{l}0 \\ 1\end{array}\right),\left(\begin{array}{lll}0 & 0 & 4\end{array}\right)$, and ( $\left.\begin{array}{lll}2 & 0 & 0\end{array}\right)$ diffraction planes, respectively. The observed diffraction peaks in recorded XRD patterns correspond to those of the standard patterns of tetragonal anatase $\mathrm{TiO}_{2}$. No other stable impurity phases were detected in the samples hence prepared materials are fully crystalline. The ratios of peak intensities in prepared powder and that of standard one was the same. The average crystallite size from XRD was calculated from X-ray line broadening of the $\left(\begin{array}{lll}1 & 0 & 1\end{array}\right)$ diffraction line using the Scherrer's equation $\left(d=\frac{0.9 \lambda}{\beta \cos \theta}\right)$ where $d$ is the grain size, $\lambda$ is the wavelength of the $\mathrm{X}$-ray $(\mathrm{Cu} \mathrm{Ka}, 0.15418 \mathrm{~nm}), \beta$ is the full-width at the half-height of the peak, and $\theta$ is the diffraction angle of the peak. The results were shown in Table 1.

\begin{tabular}{|l|l|l|}
\hline & \\
\hline
\end{tabular}

Table 1: XRD data of $\mathrm{TiO}_{2}$ nanopowder.

Calculations based on the half-widths of the (1 01 l), (0 04 ), and (2 0

0 ) diffraction peaks using the Scherrer's formula indicated that the average size of $30 \mathrm{~nm}$. The symmetry of anatase $\mathrm{TiO}_{2}$ is tetragonal I41/ amd.

\section{Transmission electron microscopy (TEM)}

The TEM image of prepared nanoparticles in Figure 2(a), shows that the $\mathrm{TiO}_{2}$ NPs are single-crystalline with the average size of $25 \mathrm{~nm}$ and the surface of the $\mathrm{TiO}_{2}$ crystals are smooth, while most part of the surface of $\mathrm{Pt}-\mathrm{TiO}_{2}$ crystals is rough, that is shown in Figure 2(b). Meanwhile, with a precise perception in Figure 2 (b), we can realize that there are some fuscous points on the $\mathrm{TiO}_{2}$ NPs surfaces. Then, $\mathrm{Pt}$ has been doped in $\mathrm{TiO}_{2}$ crystal, but they have poor homogeneity with very irregular shapes and the size range was determined to be between $50 \mathrm{~nm}$ to $80 \mathrm{~nm}$.

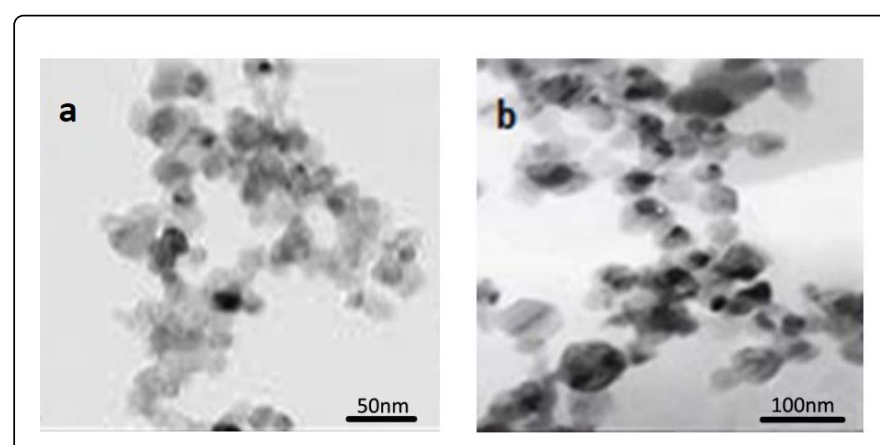

Figure 2: TEM images of (a) $\mathrm{TiO}_{2} \mathrm{NPs}$ (b) $\mathrm{Pt}_{-} \mathrm{TiO}_{2} \mathrm{NPs}$.

\section{Scanning electron microscopy (SEM)}

The $\mathrm{TiO}_{2}$ NPs were gold-covered and characterized in the Scanning Electron Microscope (SEM) to investigate their structure and surface characteristic. It was observed that the particles were spherical and were composed of approximately equal size. Nanopowders were homogeneous and fine (Figure 3). It was also possible to find out which elements constructed of a sample by EDX analyze. EDX analysis is the presence of the elements Ti, O, and Pt as presented (Figure 4).
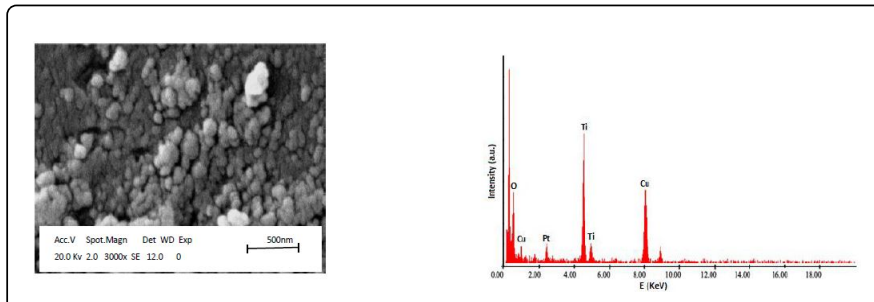

Figure 3: Scanning electron microscope of $\mathrm{Pt}-\mathrm{TiO}_{2}$ nanopowder. 
Page 4 of 7

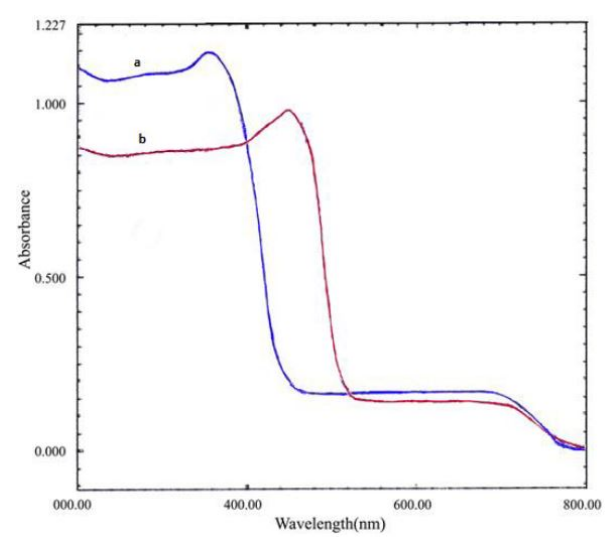

Figure 4: EDX analyzes of $\mathrm{Pt}-\mathrm{TiO}_{2}$ nanoparticles.

\section{UV-visible diffuses reflection spectra (DRS)}

The metal $\mathrm{TiO}_{2}$ doping has been also identified with UV-Visible adsorption spectra. The UV-Visible diffused spectrum of the pure $\mathrm{TiO}_{2}$ and $\mathrm{Pt} / \mathrm{TiO}_{2}$ nanopowders are seen in Figure 5. It is obviously seen that doping $\mathrm{Pt}$ on $\mathrm{TiO}_{2}$ nanopowder causes bathochromic effect, a shift of a spectral band to higher wavelengths in all the samples doping Pt reveal the redshifts of wavelength, that commonly called redshift absorption edge. This effect has an advantage in lower band gap energy of $\mathrm{TiO}_{2}$ in other words, lower energy required for electron excitation from the valence band to conduction band. The band gap energy $(\mathrm{eV})$ of each sample were calculated by following $\left(E=\frac{\mathrm{hC}}{\lambda}\right)$ equation (Table 2), where, $\lambda$ is a cut-off wavelength $(\mathrm{m}), \mathrm{C}$ is a speed of light $(3.0 \times 108$ $\mathrm{m} / \mathrm{s})$, and $\mathrm{h}$ is the Planks constant $(6.626 \times 10-34 \mathrm{Js})$.

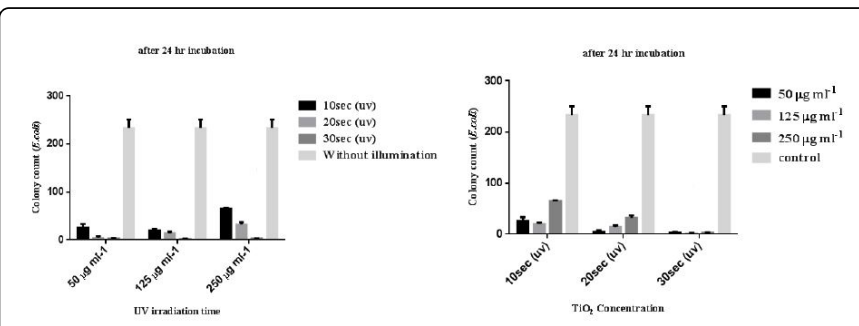

Figure 5: DRS Characterization of $\mathrm{TiO}_{2}$ (a) and $\mathrm{Pt} / \mathrm{TiO}_{2}$ (b) NPs.

\begin{tabular}{|l|l|l|}
\hline Photocatalyst & $\mathrm{TiO}_{2}$ & $\mathbf{P t} / \mathrm{TiO}_{2}$ \\
\hline Absorbance (nm) & 350 & 450 \\
\hline Bandgap (eV) & 3.5 & 2.7 \\
\hline $1 \mathrm{eV}=1.602176565 \mathrm{e}^{-19} \mathrm{~J}$ & & \\
\hline
\end{tabular}

Table 2: Correspondent wavelength and energy bandgap for $\mathrm{TiO}_{2}$ and $\mathrm{Pt} / \mathrm{TiO}_{2} \mathrm{NPs}$.

\section{Evaluation of photobactericidal effect of $\mathrm{TiO}_{2}$ and $\mathrm{Pt} / \mathrm{TiO}_{2}$ nanoparticles}

The enhancer role of $\mathrm{TiO}_{2}$ on the bactericidal effect of irradiation (photo bactericidal effect) was quantitatively evaluated by measuring the inhibitory rates (\%) of the definite dose of irradiation in presence of various concentrations of $\mathrm{TiO}_{2}$ and $\mathrm{Pt}-\mathrm{TiO}_{2} \mathrm{NPs}$. The inhibitory rates were calculated by measuring the cell viability through counting the Colony Forming Units (CFU) of E. coli or S. aureus bacteria on LB agar plates containing $\mathrm{TiO}_{2} \mathrm{NPs}$ after irradiation with UV light and Pt$\mathrm{TiO}_{2}$ after irradiation with Visible light (Tests) and also plates without $\mathrm{TiO}_{2}$ or $\mathrm{Pt}-\mathrm{TiO}_{2}$ and no irradiated (negative controls), using the following formula:

$$
\operatorname{GIR}(\%)=\frac{100 \times(\mathrm{CFUc}-\mathrm{CFU} \mathrm{T})}{(\mathrm{CFUc})}
$$

Viable bacterial counts (CFU/ml) after $24 \mathrm{~h}$ contact time showed log reduction in treated samples compared to the untreated sample. $\mathrm{CFU} / \mathrm{ml}$ at time zero is $1 \times 10^{7} \mathrm{CFU} / \mathrm{ml}$. It was shown that the optimum inactivation of bacteria $\left(\approx 10^{7} \mathrm{CFU} / \mathrm{mL}\right)$ was achieved in the presence of $0.125 \mathrm{~g} / \mathrm{L}$ NPs where $99.57 \%$ of $E$. coli and $100 \%$ of $S$. aureus were inactivated in the best condition. The $0.05 \mathrm{~g} / \mathrm{L}$ of NPs concentration is insufficient for inactivation reaction of $E$. coli and $S$. aureus. Meanwhile, at $0.25 \mathrm{~g} / \mathrm{L}$ of NP concentration, it becomes saturated in the suspension, thus give scattering effect in the medium (Table 3 and Figure 6).

\begin{tabular}{|c|c|c|c|c|c|c|c|}
\hline \multirow[t]{2}{*}{ Bacteria } & \multirow{2}{*}{$\begin{array}{l}\text { Irradiation } \\
\text { time (sec) }\end{array}$} & \multicolumn{2}{|c|}{$50 \mathrm{mg} \mathrm{ml}^{-1}$} & \multicolumn{2}{|c|}{$125 \mathrm{mg} \mathrm{ml}^{-1}$} & \multicolumn{2}{|c|}{$250 \mathrm{mg} \mathrm{ml}^{-1}$} \\
\hline & & $\begin{array}{l}\text { CFU } \\
\text { (mean } \\
\pm \text { SD) }\end{array}$ & $\begin{array}{l}\text { \%GIR } \\
\text { (mean } \\
\pm \text { SD) }\end{array}$ & $\begin{array}{l}\text { CFU } \\
\text { (mean } \\
\pm \text { SD) }\end{array}$ & $\begin{array}{l}\% \text { GIR } \\
\text { (mean } \\
\pm \text { SD) }\end{array}$ & $\begin{array}{l}\text { CFU } \\
\text { (mean } \\
\pm \text { SD) }\end{array}$ & $\begin{array}{l}\% \text { GIR } \\
\text { (mean } \\
\pm \text { SD) }\end{array}$ \\
\hline \multirow[t]{4}{*}{ E. coli } & 10 & $\begin{array}{l}25.736 \\
8 .\end{array}$ & $\begin{array}{l}89.27 \pm \\
0.5057\end{array}$ & $\begin{array}{l}20.516 \\
2 .\end{array}$ & $\begin{array}{l}91.41 \pm \\
0.8576\end{array}$ & $\begin{array}{l}65 \pm \\
1.527\end{array}$ & $\begin{array}{l}72.10 \pm \\
0.9136\end{array}$ \\
\hline & 20 & $\begin{array}{l}4.605 \\
3 .\end{array}$ & $\begin{array}{l}98.28 \pm \\
0.796\end{array}$ & $\begin{array}{l}14 \pm \\
3.055\end{array}$ & $\begin{array}{l}93.99 \pm \\
0.8271\end{array}$ & $\begin{array}{l}32 \\
4.932\end{array}$ & $\begin{array}{l}86.26 \pm \\
0.7209\end{array}$ \\
\hline & 30 & $3 \pm 1$ & $\begin{array}{l}98.71 \pm \\
0.9434\end{array}$ & $\begin{array}{l}1.527^{ \pm} \\
\end{array}$ & $\begin{array}{l}99.57 \pm \\
0.9136\end{array}$ & $\begin{array}{l}3.577 \\
0 .\end{array}$ & $\begin{array}{l}98.71 \pm \\
0.9673\end{array}$ \\
\hline & 0 & $\begin{array}{l}233 \pm \\
17.677\end{array}$ & 0 & $\begin{array}{l}233 \pm \\
17.677\end{array}$ & 0 & $\begin{array}{ll}233 & \pm \\
17.677\end{array}$ & 0 \\
\hline \multirow[t]{4}{*}{$\begin{array}{l}S . \\
\text { aureus }\end{array}$} & 10 & $\begin{array}{l}33 \\
2.516\end{array}$ & $\begin{array}{l}86.69 \pm \\
0.7627\end{array}$ & $\begin{array}{l}12 \\
3.214\end{array}$ & $\begin{array}{l}95.16 \pm \\
0.6969\end{array}$ & $36 \pm 4$ & $\begin{array}{l}85.48 \pm \\
0.6228\end{array}$ \\
\hline & 20 & $\begin{array}{l}18 \pm \\
3.214\end{array}$ & $\begin{array}{l}92.74 \pm \\
0.6969\end{array}$ & ${ }_{2.516}^{4} \pm$ & $\begin{array}{l}98.38 \pm \\
0.7627\end{array}$ & ${ }_{1.527} \pm$ & $\begin{array}{l}96.77 \pm \\
0.856\end{array}$ \\
\hline & 30 & $\begin{array}{ll}1 & \pm \\
0.577^{-}\end{array}$ & $\begin{array}{l}99.59 \pm \\
0.9455\end{array}$ & 0 & 100 & $4_{1.154} \pm$ & $\begin{array}{l}93.38 \pm \\
0.8911\end{array}$ \\
\hline & 0 & $\begin{array}{l}248 \quad \pm \\
10.606\end{array}$ & 0 & $\begin{array}{l}248 \pm \\
10.606\end{array}$ & 0 & $\begin{array}{l}248 \quad \pm \\
10.606\end{array}$ & 0 \\
\hline
\end{tabular}

Table 3: Effect of different concentrations of $\mathrm{TiO}_{2} \mathrm{NPs}$ on $E$. coli and $S$. aureus viability under irradiation, $24 \mathrm{~h}$ of incubation. 


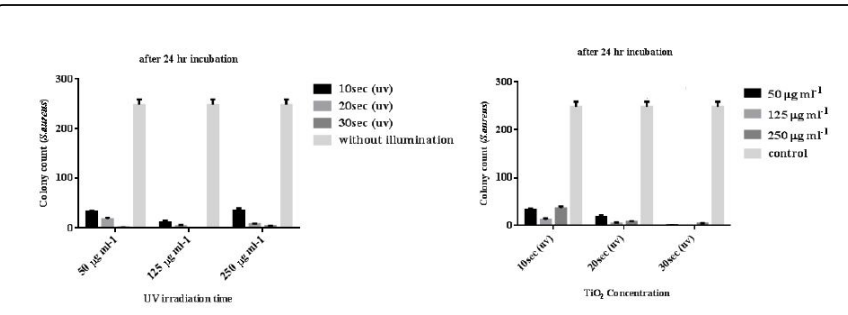

Figure 6: Effect of different concentrations of $\mathrm{TiO}_{2} \mathrm{NPs}$ on $E$. coli and $S$. aureus viability under irradiation.

Also, the antibacterial efficacy of the $\mathrm{TiO}_{2}$ and $\mathrm{Pt} / \mathrm{TiO}_{2} \mathrm{NPs}$ was determined using two shake flask methods; one with $\mathrm{NB}$ as the medium, and another with NB and nanoparticles. In the case of the NB test, bacterial growth was monitored by measuring the optical density of the medium over time. The microbial reduction percentage with the $\mathrm{TiO}_{2}$ and $\mathrm{Pt} / \mathrm{TiO}_{2} \mathrm{NPs}$ for both species of bacteria is shown in Tables 4 and 5 respectively.

\begin{tabular}{|l|l|l|l|l|l|}
\hline \multirow{2}{*}{$\begin{array}{l}\text { Test } \\
\text { Organism }\end{array}$} & \multicolumn{3}{|l|}{ O.D after 24 hours (in $660 \mathrm{~nm})$} & $\begin{array}{l}\text { \%Reduction after 30 } \\
\text { sec UV irradiation }\end{array}$ \\
\cline { 2 - 6 } & $\begin{array}{l}\text { Control } \\
\text { (Untreated) }\end{array}$ & \multicolumn{2}{|l|}{$\begin{array}{l}\mathrm{TiO}_{2} \text { nanoparticles } \\
\left(\mathbf{0 . 1 2 5} \mathbf{~ m ~ m l}^{-1}\right)\end{array}$} & \\
\hline E. coli & $2 \times 1010$ & 400 & $1.15 \times 107$ & 23 & 94.3 \\
\hline S. aureus & $1.2 \times 1010$ & 240 & $2.5 \times 108$ & 5 & 98 \\
\hline
\end{tabular}

Table 4: Results of NB shake flask test in terms of growth reduction percentage with $\mathrm{TiO}_{2}$.

\begin{tabular}{|l|l|l|l|l|l|}
\hline \multirow{2}{*}{$\begin{array}{l}\text { Test } \\
\text { Organis } \\
\mathbf{m}\end{array}$} & \multicolumn{3}{|l|}{ O.D after 24 hours (in 660 nm) } & $\begin{array}{l}\text { \%Reduction after 30 } \\
\text { sec Visible irradiation }\end{array}$ \\
\cline { 2 - 5 } & $\begin{array}{l}\text { Control } \\
\text { (Untreated) }\end{array}$ & \multicolumn{2}{|l|}{$\begin{array}{l}\text { Pt/TiO } \\
\text { Nanoparticles (0.1\%) }\end{array}$} & \multicolumn{1}{|l}{} \\
\hline E. coli & $2 \times 1010$ & $\begin{array}{l}40 \\
0\end{array}$ & $2.8 \times 107$ & 56 & 86 \\
\hline S. aureus & $1.2 \times 1010$ & $\begin{array}{l}24 \\
0\end{array}$ & $1.2 \times 108$ & 24 & 90 \\
\hline
\end{tabular}

Table 5: Results of NB shake flask test in terms of growth reduction percentage with $\mathrm{Pt} / \mathrm{TiO}_{2}$.

In Figure 7, graphs are included showing the change in absorbance over time. A very high antimicrobial activity was seen against both bacteria.

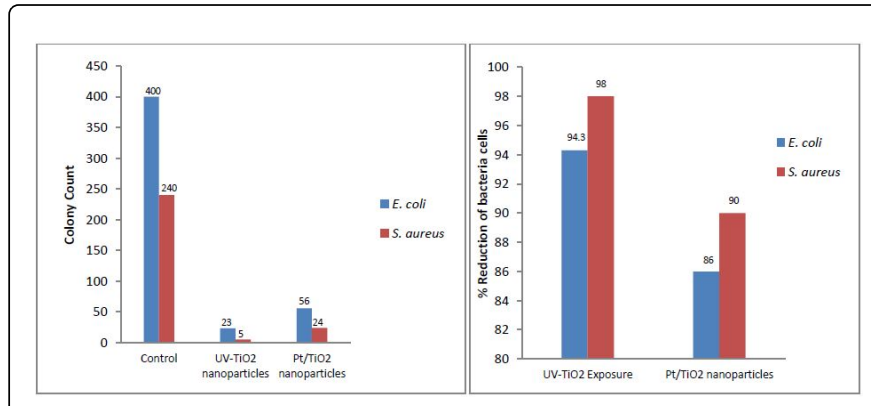

Figure 7: The viability of $E$. coli and $S$. aureus bacteria cells after incubating with $\mathrm{TiO}_{2}(125 \mu \mathrm{g} / \mathrm{mL})$ and $\mathrm{Pt} / \mathrm{TiO}_{2}$ suspensions $(0.1 \%)$ for $24 \mathrm{~h}$ with $250 \mathrm{rpm}$ shaking speed at $37^{\circ} \mathrm{C}$. Loss of viability was calculated by the following formula: loss of viability $\%=\{$ (counts of control-counts of samples after incubation with suspensions)/ counts of control $\} \times 100$.

Absorbance measurements (Turbidity) are not as accurate as plate counts for the determination of viable bacteria but they can give a rapid estimate of cell numbers and are commonly used for Minimum Inhibitory Concentration (MIC) tests.

Using the absorbance value shown in Tables 4 and 5 after $24 \mathrm{~h}$ of incubation, there were $94.3 \%$ and $86 \%$ reduction in growth for $E$. coli with the $\mathrm{TiO}_{2}$ and $\mathrm{Pt} / \mathrm{TiO}_{2}$ NPs respectively followed by $98 \%$ and $90 \%$ reduction in growth for $S$. aureus.

\section{Discussion}

We have demonstrated that $\mathrm{Pt} / \mathrm{TiO}_{2}$ nanoparticles are effective nanoparticles for inhibiting the cell growth of several pathogenic bacteria under illumination by UV-Visible light. In this study, The $\mathrm{TiO}_{2}$ and $\mathrm{Pt} / \mathrm{TiO}_{2}$ nanoparticles were synthesized with inorganic substrates by a sol-gel method that showed a very high degree of antibacterial activity when compared to control. Overall the results demonstrated a slightly higher antibacterial activity against $S$. aureus than $E$. coli. Benabbou et al. found that it is possible to increase the percentage of bacterial inactivation by increasing the crystallinity of $\mathrm{TiO}_{2} \mathrm{NPs}$ via calculations as was resulted within the present experiment [34]. In this research, we used $\mathrm{TiO}_{2}$ crystalline with $100 \%$ anatase phase. Sunada et al. found that the mechanism of $\mathrm{TiO}_{2}$-associated photocatalysis on bacteria could be divided into three stages: Firstly, the outer membrane of the bacteria was attacked and partially decomposed by reactive species such as $\mathrm{OH}^{\bullet}, \mathrm{O}_{2}^{-}$, and $\mathrm{H}_{2} \mathrm{O}_{2}$; then disordering of the inner membrane leading to the lipid peroxidation threatening cell life; finally, cell death and destruction [35] (Figure 8). According to Fujishima et al. research, if the fluorescent illumination continues for a sufficient time, bacteria will be completely mineralized into $\mathrm{CO}_{2}, \mathrm{H}_{2} \mathrm{O}$, and other mineral components [36]. 


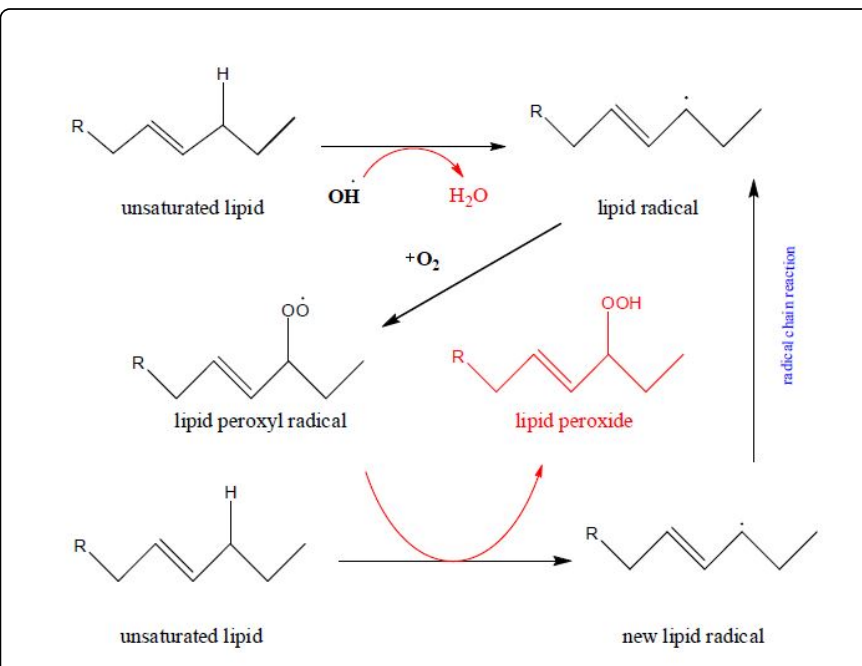

Figure 8: Schematic of lipid peroxidation.

The visible-light-responsive $\mathrm{Pt} / \mathrm{TiO}_{2} \mathrm{NPs}$ can be achieved via a solgel method followed by photoreduction. UV curing technique can be applied for activating anatase $\mathrm{TiO}_{2}$ photocatalytic reactivity of the prepared powder. These powder posse favorite surface properties such as good adhesion, high porosity, and eligible Pt distribution onto the $\mathrm{TiO}_{2}$ powder. The optimal $\mathrm{Pt}$ doping $\left(0.1 \%\right.$ mole) to $\mathrm{TiO}_{2}$ powder provides the synergistic effect on the photocatalytic reactivity. Pt plays a pivotal role in increasing hydrophilicity as well as extending the light absorption spectrum toward the visible region in the benefit of photocatalytic activity. The illumination time required in this approach is shorter than that has been applied in previous studies. Given improvement can be potentially attributed to two main factors. First, optimally sized nanoprobes contributing to the highly efficient energy transfer from UV light to the target bacteria. Second, the targeting capacity of the nanoprobes for several bacteria also results in the effectiveness of the cell growth inhibition of these bacteria. Although the transmission of UV light is limited, this approach should potentially be suitable for the treatment of infections.

Results of the bactericidal investigation indicate that $\mathrm{Pt} / \mathrm{TiO}_{2} \mathrm{NPs}$, as an extremely stable metal-semiconductor nanomaterial, can exhibit a very high photodynamic efficiency under visible irradiation, and our $\mathrm{Pt} / \mathrm{TiO}_{2}$ NPs showed to be relatively effective in the antibacterial property.

\section{Conclusion}

In summary, we have presented a facile and efficient synthetic route for the preparation of Pt-doped Titanium dioxide NPs, which has potential applications on the development of an antibacterial material in both in vitro and in vivo settings. In conclusion, the $\mathrm{TiO}_{2} \mathrm{NPs}$ sizes of $20 \mathrm{~nm}$ possess significant antibacterial properties against $E$. coli and $S$. aureus. Our results suggested that the $\mathrm{TiO}_{2} \mathrm{NPs}$ have greater efficacy in inhibiting the growth of S. aureus compared to the E. coli and its inhibitory effects increases as the concentrations of $\mathrm{TiO}_{2} \mathrm{NPs}$ increased. The concluded MIC for E. coli and $S$. aureus was $125 \mu \mathrm{g} / \mathrm{mL}$. The antimicrobial mechanisms of the $\mathrm{TiO}_{2}$ NPs suggested that oxidation capacity of NPs toward GSH oxidation stress were responsible for antimicrobial behavior of $\mathrm{TiO}_{2} \mathrm{NPs}$. The results of $E$. coli and $S$. aureus suggest that $\mathrm{TiO}_{2}$ nanoparticles can be used to control the growth of pathogenic bacteria. The results from this work are aiding the scale-up of a spray coating process for the production of efficient and economical antibacterial surfaces. Therefore, these surfaces have considerable potential to be recruited in medical instrumentation, water purification systems, hospitals decontaminants, dental office equipment, food storage, packaging, and household sanitation. These findings suggest that $\mathrm{Pt}$-doped $\mathrm{TiO}_{2}$ has potential application in the development of alternative disinfectants for environmental and medical usages.

\section{Acknowledgment}

We are thankful to Avicenna Research Institute for supporting this work.

\section{References}

1. Donnell GM, Russell AD (1999) Antiseptics and disinfectants: activity, action, and resistance. Clin Microbiol Rev 12: 147-179.

2. Stoimenov PK, Rosalyn LK, George LM, Klabunde KJ (2002) Metaloxide nanoparticles as bactericidal agents. Langmuir 18: 6679-6686.

3. Hajipour MJ, Katharina MF, Ashkarran AK, Dorleta JA, Idoia RL, et al. (2012) Antibacterial properties of nanoparticles. Trends Biotechnol 30: 499-511.

4. Ameer A, Arham SA, Mohammad O, Mohammad SK, Sami SH, et al. (2012) Antimicrobial activity of metal oxide nanoparticles against Grampositive and Gram-negative bacteria: a comparative study. Int J Nanomed 30: 6003-6009.

5. Solmaz MD, Farzaneh L, Mohammad BJ, Mohammad HZ, Khosro A (2014) Antimicrobial activity of the metals and metal oxide nanoparticles. Mater Sci Eng C 44: 278-284.

6. Thangaraju N, Venkatalakshmi RP, Chinnasamy A, Kannaiyan P (2012) Synthesis of silver nanoparticles and the antibacterial and anticancer activities of the crude extract of Sargassumpolycystum C. Agardh Nano Biomed Eng 4: 89-94.

7. Tripathi RM, Rana D, Shrivastav A, Singh RP, Shrivastavd BR (2013) Biogenic synthesis of silver nanoparticles using Saraca indica leaf extract and evaluation of their antibacterial activity. Nano Biomed Eng 5: 50-56.

8. Bahareh S, Sedigheh M, Mehdi A (2014) Investigation of antibacterial effect of Cadmium Oxide nanoparticles on Staphylococcus aureus bacteria J Nanobiotechnol 12: 26.

9. Prucek R, Tucek J, Kilianova M, Panacek A, Kvitek L, et al. (2011) The targeted antibacterial and antifungal properties of magnetic nanocomposite of iron oxide and silver nanoparticles. Biomater 32: 4704-4713.

10. Pin CM, Sharon S, Daniel MB, Zheng H, Edward JW, et al. (1999) Bactericidal activity of photocatalytic $\mathrm{TiO}_{2}$ reaction: Toward an understanding of its killing mechanism. Appl Environ Microbiol 65: 4094-4098.

11. Ting MT, Hsin HC, Kia CC, Yu L, Chun CT (2010) A comparative study of the bactericidal effect of photocatalytic oxidation by $\mathrm{TiO}_{2}$ on antibioticresistant and antibiotic-sensitive bacteria. J Chem Technol Biotechnol 85: 1642-1653.

12. Howard AF, Iram BD, Sajnu V, Alex S (2011) Photocatalytic disinfection using titanium dioxide: spectrum and mechanism of antimicrobial activity. Appl Microbiol Biotechnol 90: 1847-1868.

13. Priyanka A, Ganesh K, Suresh G, Anjali R (2015) Synthesis of $\mathrm{TiO}_{2}$ nanoparticles by electrochemical method and their antibacterial application. Arabian J Chem.

14. Pinggui W, Rongcai X, Kari I, Jian KS (2010) Visible-light-induced bactericidal activity of Titanium dioxide codoped with Nitrogen and Silver. Environ Sci Technol 44: 6992-6997.

15. Michael VL, Erika LB, Vicki LC, Qilin L (2011) Virus inactivation by silver doped titanium dioxide nanoparticles for drinking water treatment. Water Res 45: 535-544. 
16. Pramanik A, Laha D, Bhattacharya D, Pramanik P, Karmakar P (2012) A novel study of antibacterial activity of copper iodide nanoparticle mediated by DNA and membrane damage. Colloids Surf B 96: 50-55.

17. Osamu Y, Toshiaki O, Kelly A, Fukuda M (2010) Antibacterial characteristics of $\mathrm{CaCO}_{3}-\mathrm{MgO}$ composites. Mater Sci Eng B 173: 208-211.

18. Dong CX, Song DL, John C, Orville LM, He GH, et al. (2011) Antibacterial study of $\mathrm{Mg}(\mathrm{OH})_{2}$ nanoplatelets. Mater Res Bull 46: 576-82.

19. Raghupathi KR, Koodali RT, Manna AC (2011) Size-dependent bacterial growth inhibition and mechanism of antibacterial activity of zinc oxide nanoparticles. Langmuir 27: 4020-4028.

20. Sirelkhatim A, Mahmud S, Seeni A, Mohamad Kaus NH, Ann LC, et al. (2015) Review on zinc oxide nanoparticles: antibacterial activity and toxicity mechanism. Nano-Micro Letters 7: 219-242.

21. Irannejada $\mathrm{A}$, Janghorbana $\mathrm{K}$, Tanb $\mathrm{OK}$, Huangb $\mathrm{H}$, Limb $\mathrm{CK}$, et al. (2011) Effect of the $\mathrm{TiO}_{2}$ shell thickness on the dye-sensitized solar cells with $\mathrm{ZnO}-\mathrm{TiO}_{2}$ core-shell nanorod electrodes. Electrochimica Acta 58 19-24.

22. Robert P, Memarzadeh AK (2014) Nanoparticles and the control of oral infections. Int J Antimicrob Agents 43: 95-104.

23. Hashimoto K, Irie H, Fujishima A (2005) $\mathrm{TiO}_{2}$ photocatalysis: A historical overview and future prospects. Jpn J Appl Phys 44: 8269-8285.

24. Hirakawa K, Mori M, Yoshida M, Oikawa S, Kawanishi S (2004) Photoirradiated titanium dioxide catalyzes site specific DNA damage via generation of hydrogen peroxide. Free Radic Res 38: 439-447.

25. Kiwi J, Nadtochenko V (2005) Evidence for the mechanism of photocatalytic degradation of the bacterial wall membrane at the $\mathrm{TiO}_{2}$ interface by ATR-FTIR and laser kinetic spectroscopy. Langmuir 21: 4631-4641.

26. Mori K (2005) Photo-functionalized materials using nanoparticles: Photocatalysis. KONA 23: 205-214.
27. Bessekhouad Y, Robert D, Weber JV (2003) Synthesis of photocatalytic $\mathrm{TiO}_{2}$ nanoparticles: optimization of the preparation conditions. J Photochem Photobiolo A Chem 157: 47-53.

28. Sharmila Devi R, Venckatesh R, Sivaraj R (2014) Synthesis of titanium dioxide nanoparticles by sol-gel technique. Int J Innov Res Sci Eng Technol 3: 15206-15211.

29. Vetrivel V, Rajendran K, Kalaiselvi V (2015) Synthesis and characterization of Pure Titanium dioxide nanoparticles by Sol-gel method. Int J ChemTech Res 7: 1090-1097.

30. Zaleska A (2008) Doped- $-\mathrm{TiO}_{2}$ : A review. Recent Patents Eng 2: 157-164.

31. Chen H, Chen S, Quan X, Yu HT, Zhao HM, et al. (2008) Fabrication of $\mathrm{TiO}_{2}-\mathrm{Pt}$ coaxial nanotube array schottky structures for enhanced photocatalytic degradation of phenol in aqueous solution. J Phys Chem C 112: 9285-9290.

32. Choi J, Park H, Hoffmann MR (2009) Combinatorial doping of $\mathrm{TiO}_{2}$ with Platinum (Pt), Chromium (Cr), Vanadium (V), and Nickel (Ni) to achieve enhanced photocatalytic activity with visible light irradiation. J Mat Res 25: 149-158.

33. Wong MS, Sun DS, Chang HH (2010) Bactericidal performance of visible light responsive titania photocatalyst with silver nanostructures. PLoS One 5: e10394.

34. Benabbou AK, Derriche Z, Felix C, Lejeune P, Guillard C (2007) Photocatalytic inactivation of Escherichia coli, effect of concentration of titanium dioksida and microorganism, nature and intensity of UV irradiation. App Cat B Environ 76: 257-263.

35. Sunada K, Watanabe T, Hashimoto K (2003) Studies on photokilling of bacteria on $\mathrm{TiO}_{2}$ thin film. J Photochem Photobiol A Chem 156: 227-233.

36. Fujishima A, Rao TN, Tryk DA (2000) Titanium dioxide photocatalysis. J Photochem Photobiol C: Photochem Rev 1: 1-12. 